\title{
Merkel Cell Carcinoma pNX TNM Finding v8
}

National Cancer Institute

\section{Source}

National Cancer Institute. Merkel Cell Carcinoma pNX TNM Finding v8. NCI Thesaurus.

Code C136861.

Merkel cell carcinoma in which the regional lymph nodes cannot be assessed (e.g., previously removed for another reason or not removed for pathologic evaluation). (from AJCC 8th Ed.) 